\title{
Gall Stones in Patients with Disorders of the Terminal Ileum and Disturbed Bile Salt Metabolism*
}

\author{
K. W. HEATON, $\dagger$ M.D., M.R.C.P. ; A. E. READ, $\ddagger$ M.D., F.R.C.P.
}

British Medical fournal, 1969, 3, 494-496

\begin{abstract}
Summary : In a combined historical and radiological survey gall stones were found in 23 out of 72 patients with disorders of the terminal ileum $(31.9 \%)$. This is four to five times the expected incidence of cholelithiasis. In these patients the incidence of gall stones was not related to age, but did, however, increase with increased duration of the ileal disorder. Glycine/taurine conjugation ratios of bile salts in the bile were abnormally high in 10 out of 11 patients with ileal disorders. Both impaired bile salt recirculation and absorption of poorly soluble bacterially degraded bile salts are possible causes of cholelithiasis in these patients.
\end{abstract}

\section{Introduction}

It has recently been shown that in patients with disorders of the distal small intestine there is a breakdown in the enterohepatic circulation of bile salts (Austad et al., 1967 ; Hardison and Rosenberg, 1967). Furthermore, in these patients bile salt pool sizes are decreased (Heaton et al., 1968), and this is reflected in subnormal concentrations of bile salts in the duodenum during digestion (Hardison and Rosenberg, 1967 ; Krone et al., 1968; McLeod and Wiggins, 1968 ; van Deest et al., 1968). Since bile salts are necessary to maintain bile in a supersaturated, micellar state (Small, 1967) it has been suggested that patients with distal small-bowel disorders might have an increased incidence of gall stones (Hofmann, 1967; Heaton, 1968). To date there has been no evidence for or against this hypothesis. In the present study we have made a survey of the incidence of gall stones in patients with disorders of the terminal ileum. In some patients the conjugation pattern of bile salts in the bile was determined as an index of the integrity of the enterohepatic circulation.

\section{Patients and Methods}

A total of 72 patients with ileal disorders were studied (Table I). They were all chosen as having a definite disorder of the terminal ileum of at least 18 months' duration, this being defined as surgical resection or bypass of at least 12 in. $(30 \mathrm{~cm}$.) of the terminal ileum as estimated at laparotomy, or of at least $24 \mathrm{~cm}$. by measurement of the formalin-fixed (and therefore shrunken) specimen. The distal end of the "lost" ileum was in all cases within $20 \mathrm{~cm}$. of the ileocaecal valve. Resection or bypass of a smaller amount was accepted if the operation was followed by radiologically demonstrated recurrent Crohn's disease in the remaining ileum. Patients who had had removal of an unrecorded length of terminal ileum were included if there was persistent postoperative diarrhoea, since in our experience diarrhoea is seldom troublesome after operations involving less than $30 \mathrm{~cm}$. of intestine. In all, 62 patients had undergone surgical procedures. In 57 cases the operative diagnosis was Crohn's disease; the disease recurred postoperatively in 38 patients, and also involved the colon in nine.

\footnotetext{
* This paper was presented in part before the Scientific Meeting of the British Society of Gastroenterology on 25 April 1969.

Lecturer in Medicine, University of Bristol.
$¥$ Professor of Medicine, University of Bristol.

$¥$ Professor of Medicine, University of Bristol.
Department of Medicine, Bristol Royal Infirmary, Bristol BS2 $8 \mathrm{HW}$.
}

In the other five operated cases surgery had been performed on account of carcinoid tumour (2), trauma (2), or gangrene (1). In all but two of the 62 surgically treated cases the caecum or right colon had also been resected or bypassed.

Of the 10 patients who had not undergone surgical treatment all had extensive chronic Crohn's disease of the terminal ileum, and in four cases the colon was also affected. The disease was clinically inactive or only moderately active in all patients. In those surgically treated cases in which measurements had been recorded, the length of ileum resected or bypassed varied from 12 in. $(30 \mathrm{~cm}$.) to $12 \mathrm{ft}$. $(3.66 \mathrm{~m}$.) by the surgeon's estimate (median 27 in.; $68.6 \mathrm{~cm}$.) and from 18 to $110 \mathrm{~cm}$. by the pathologist's measurement (median $50 \mathrm{~cm}$.). In only five patients was more than $4 \mathrm{ft}$. $(122 \mathrm{~cm}$.) of the ileum removed or bypassed.

Comparison Groups.-It was not practicable to study radiologically a large matched control group of the general population. For calculating the expected incidence of gall stones in the patients studied use was made of the published results of a large-scale unselected necropsy survey (Torvik and Høivik, 1960). In addition, a contrast group was studied in the form of 100 consecutive outpatients attending a clinic with ill-defined gastrointestinal complaints, which included abdominal pain, dyspepsia, and diarrhoea. Such patients, who were otherwise unselected, were as part of another investigation asked to undergo a comprehensive radiological survey of the alimentary tract which included oral cholecystography. This contrast group consisted of patients of about the same age and sex distribution as the patients with ileal disorders (Table I).

\begin{tabular}{|c|c|c|c|c|c|c|c|c|c|c|c|c|}
\hline \multirow{3}{*}{$\begin{array}{l}\text { Age } \\
\text { Group }\end{array}$} & \multicolumn{6}{|c|}{ Ileal Disorders } & \multicolumn{6}{|c|}{ Contrast Group } \\
\hline & \multicolumn{3}{|c|}{ Total No. } & \multicolumn{3}{|c|}{ No. with Stones } & \multicolumn{3}{|c|}{ Total No. } & \multicolumn{3}{|c|}{ No. with Stones } \\
\hline & $M$ & $\mathrm{~F}$ & $\mathrm{~T}$ & $\mathbf{M}$ & $\mathrm{F}$ & $T$ & M & $\mathrm{F}$ & $T$ & $M$ & $\mathbf{F}$ & $\mathbf{T}$ \\
\hline $\begin{array}{l}20-29 \\
30-39 \\
40-49 \\
50-59 \\
60-69\end{array}$ & $\begin{array}{r}5 \\
8 \\
10 \\
4 \\
6\end{array}$ & $\begin{array}{r}3 \\
12 \\
12 \\
7 \\
5\end{array}$ & $\begin{array}{r}8 \\
20 \\
22 \\
11 \\
11\end{array}$ & $\begin{array}{l}0 \\
3 \\
2 \\
0 \\
3\end{array}$ & $\begin{array}{l}1 \\
5 \\
5 \\
3 \\
1\end{array}$ & $\begin{array}{l}1 \\
8 \\
7 \\
3 \\
4\end{array}$ & $\begin{array}{r}10 \\
15 \\
10 \\
10 \\
3\end{array}$ & $\begin{array}{r}12 \\
9 \\
7 \\
12 \\
12\end{array}$ & $\begin{array}{l}22 \\
24 \\
17 \\
22 \\
15\end{array}$ & $\begin{array}{l}0 \\
0 \\
1 \\
1 \\
1\end{array}$ & $\begin{array}{l}1 \\
1 \\
1 \\
4 \\
2\end{array}$ & $\begin{array}{l}1 \\
1 \\
2 \\
5 \\
3\end{array}$ \\
\hline Total & 33 & 39 & 72 & 8 & 15 & 23 & 48 & 52 & 100 & 3 & 9 & 12 \\
\hline
\end{tabular}

Evidence of Cholelithiasis.-Initially the hospital notes were searched for a history of cholecystectomy or other surgical treatment for gall stones. If this was absent the patient underwent oral cholecystography, performed in the conventional manner and with sodium ipodate as the contrast material. A double dose of sodium ipodate was given to one patient in whom the normal dose failed to opacify the gall bladder, and one patient underwent intravenous cholangiography.

Bile Salt Conjugation Patterns.-In certain patients bile was obtained by duodenal intubation of the fasting subject followed by gall bladder stimulation with purified cholecystokininpancreozymin. ${ }^{1}$ Bile samples were analysed by the method of Garbutt et al. (1969) to determine the ratio of glycine-conjugated to taurine-conjugated bile salts.

${ }^{1}$ CCK-PZ, supplied by Professor E. Jorpes, Karolinska Institute, Stockholm, Sweden. 


\section{Results}

Of the 72 patients with disorders of the terminal ileum a total of $23(31.9 \%)$ were found to have or to have had gall stones. Six patients had already undergone cholecystectomy for stones, while in one patient cholecystolithotomy had been performed. In 14 cases gall stones were demonstrated radiologically. One patient had a gall bladder which showed no shadow with sodium ipodate, and the one patient who died was found at necropsy to have gall stones. Calculi were found in 8 of the 33 men $(24 \cdot 2 \%)$ and in 15 of the 39 women $(38.5 \%)$.

From necropsy data (Torvik and Høivik, 1960) the expected incidence of gall stones in 72 subjects of this age and sex distribution is $5.38(7.5 \%)$. The difference of the observed from the expected incidence is statistically highly significant $(t=7 \cdot 895, \mathrm{P}<0 \cdot 001)$.

In the contrast group gall stones were found in 12 of the 100 patients $(12 \%)$. This group included one patient who had already undergone cholecystectomy. Three of the 48 men $(6.25 \%)$ and 9 of the 52 women $(17 \cdot 3 \%)$ had cholelithiasis. The difference in incidence of gall stones from that found in patients with ileal disorders is statistically significant (after standardizing for age and sex, $\left.\chi^{2}=5.98, \mathrm{P}<0.02\right)$. On clinical grounds cholelithiasis was suspected in 5 of these 12 patients. If these patients had been excluded the incidence of gall stones in the contrast group would have approximated that of those subjected to necropsy in the general population.

Gall Stone Incidence and Age and Sex (Table I).-A constant finding in necropsy series is that with advancing age there is a steady increase in the incidence of cholelithiasis. This trend was also evident in the contrast group; below the age of 40 gall stones were found in only 2 out of the 46 patients ( $4 \cdot 3 \%$ ), whereas over the age of 4010 out of 54 had stones $(18.5 \%)$. In the patients with ileal disorders, however, this relation of gall stone incidence with age was not apparent. Below the age of 40 , stones were found in 9 out of 28 patients $(32 \cdot 1 \%)$ and over this age in 14 out of $44(31.8 \%)$. Necropsy series show gall stones to be about twice as common in women as in men. This female preponderance occurred in the analysis of patients with ileal disorders (female/male incidence ratio 1.6) and was also evident in the contrast group (female/male ratio $2 \cdot 8$ ).

TABLE II.-Gall Stone Incidence in Relation to Duration of Ileal Disorder in 62 Surgically Treated Patients

\begin{tabular}{|c|c|c|c|c|}
\hline \multirow{2}{*}{\multicolumn{2}{|c|}{$\begin{array}{l}\text { Time Lapse since First } \\
\text { Operation on } \\
\text { Terminal Ileum }\end{array}$}} & \multirow{2}{*}{$\begin{array}{c}\text { Total } \\
\text { No. of } \\
\text { Patients }\end{array}$} & \multicolumn{2}{|c|}{ With Gall Stones } \\
\hline & & & No. & $\%$ \\
\hline $\begin{array}{l}1-5 \text { years } \\
5-15 \text { years } \\
\text { Over } 15 \text { years }\end{array}$ & $\begin{array}{l}\because \\
\because\end{array}$ & $\begin{array}{l}15 \\
35 \\
12\end{array}$ & $\begin{array}{l}2 \\
8 \\
9\end{array}$ & $\begin{array}{l}13.3 \\
22.9 \\
75.0\end{array}$ \\
\hline
\end{tabular}

Gall Stone Incidence and Duration of Ileal Disorder (Table II).-In only the surgically treated patients was it possible to state confidently the duration of the ileal disorder. In Table II the time lapse since the first operation on the terminal ileum is related to gall stone incidence, and shows that with increased duration of the ileal disorder there was an increased incidence of gall stones. This was most striking in the group first operated on over 15 years ago. Nine out of $12(75 \%)$ of these patients were found to have stones. This group did not contain a majority of elderly patients, the mean age of the eight women being 47.5 years and of the four men 58.0 years.

Manifestations of Gall Stones in Patients with Terminal Ileal Disorders.-Only 5 of the 23 patients with cholelithiasis had had definite biliary tract symptoms (biliary colic and jaundice), whereas in the other 18 patients (78.3\%) the gall stones were apparently asymptomatic. Of the 17 patients with intact gall bladders all but two had undergone oral cholecystography. Of these 15 gall bladders, $11(73.3 \%)$ concentrated the sodium ipodate sufficiently to become opaque on radio- graphy. Note was also made of the radio-opacity or translucency of the gall stones. Of the 21 patients of whom radicgraphs had been taken $12(57 \cdot 1 \%)$ had radio-opaque calculi (three solitary, eight multiple, and one associated with limy bile). Four out of five cholecystectomy patients had opaque calculi, which may explain why in four cases this operation was performed in the absence of biliary tract symptoms. Eight patients were shown to have translucent stones (three solitary and five multiple).

Bile Salt Conjugation Patterns.-Measurements of the glycine/taurine conjugation $(\mathrm{G} / \mathrm{T})$ ratio were made in 11 patients with disorders of the terminal ileum. The normal $\mathrm{G} / \mathrm{T}$ ratio has been previously established as ranging from 1.4 to 6.0 (Sjövall, 1960), and we have obtained values in the same range in normal subjects (Heaton, 1968 ; Garbutt et al., 1969). In the 11 patients in this study the $G / T$ ratio was high in all but one case. Six patients without gall stones had a mean $\mathrm{G} / \mathrm{T}$ ratio of 11.7 (range $2 \cdot 6$ to $19 \cdot 6$ ). Five patients with gall stones had a mean $\mathrm{G} / \mathrm{T}$ ratio of $12 \cdot 1$ (range $8 \cdot 1$ to $16 \cdot 9$ ).

\section{Discussion}

This study has shown an association between cholelithiasis and disorders of the terminal ileum. The incidence of gall stones in patients with ileal disorders was over four times the expected incidence as calculated from a large necropsy survey of the general population (Torvik and Høivik, 1960). This report was chosen for comparison because it contains the only recent large necropsy series from a west European country with comprehensive data on gall stone incidence including cholecystectomies. Furthermore, it is based on a high proportion $(45 \%)$ of all the deaths occurring in a city (Oslo) comparable in size and character to Bristol. The Birmingham necropsy survey of Horn (1956) does not include cholecystectomies. If, however, to Horn's figures are added the probable number of cholecystectomies $(7.7 \%$ in the Oslo series), and the adjusted data are then used to calculate the expected incidence of gall stones in our 72 patients with ileal disorders, the figure obtained is $4: 63$ patients. This is less than the Oslo-based figure (5.39) and emphasizes the significance of the observed incidence of 23 patients. Other necropsy surveys give similar figures to the ones quoted (Gross, 1929 ; Lieber, 1952 ; Kozoll et al., 1959). The high proportion of cholecystectomies in the present study may be explained by the likelihood of abdominal radiographs being taken in patients with Crohn's disease and of their gall stones being opaque.

The incidence of cholelithiasis in patients with ileal disorders was also significantly greater than that in the-contrast group. In this latter group gall stones were, as expected, commoner in the older age groups. In the study group, however, the normal dependence of gall stone incidence on age seemed to be replaced by a correlation with the duration of the ileal disorder. We suggest, therefore, that cholelithiasis be regarded as a late complication of disorders of the terminal ileum and as an integral part of the syndrome of cholerhoeic enteropathy (Hofmann, 1967).

The mechanism of this association remains to be worked out, but there is some evidence that it is due to secretion of lithogenic bile rather than to infection or other pathology in the biliary tract. For instance, the great majority of these gall stones were asymptomatic, and in addition they were usually present in gall bladders which retained their concentrating function, as judged radiologically. Gall bladders containing stones usually retain this function in only 35 to $48 \%$ of cases (Gordon, 1953 ; Rominger and Lockwood, 1963 ; Wenckert and Robertson, 1966).

As to the nature of the metabolic defect leading to stone formation, two findings must be taken into account. Firstly, an unusually large proportion $(57 \cdot 1 \%)$ of the gall stones were radio-opaque and therefore rich in calcium. It is generally 
believed that only $20 \%$ of biliary calculi are opaque (Shehadi, 1968), though figures quoted by other authorities vary from 10 to $30-40 \%$ (Sleisenger, 1967 ; Sherlock, 1968). In the contrast group of the present study only 2 out of 11 calculi were opaque $(18 \cdot 2 \%)$. Secondly, we have confirmed that there is an almost constant abnormality of bile salt conjugation in the bile of patients with disorders of the terminal ileum (McLeod and Wiggins, 1968 ; Garbutt et al., 1969). The G/T ratio was raised in all five patients with gall stones in whom it was measured. This may be relevant to the pathogenesis of these stones. Other studies (Heaton, 1968 ; Garbutt et al., 1969) have shown that a high $G / T$ ratio is a constant finding when the enterohepatic circulation is interrupted by ileal disorders, and that it is probably due to unavailability of taurine in the face of increased demands for synthesis of conjugated bile salts. The $G / T$ ratio is also high in patients with the stagnant loop syndrome (Tabaqchali et al., 1968). In such patients there is excessive bacterial deconjugation of bile salts (Tabaqchali and Booth, 1966) and therefore presumably increased demand for reconjugation, if not for synthesis. It is likely, therefore, that in the patients studied here there was an increased turnover of bile acid side-chains, due either to malabsorption of bile salts or to excessive exposure of them to intestinal bacteria. There is experimental evidence that either of these phenomena could lead to cholelithiasis.

Artificial interruption of the enterohepatic circulation causes a fall in the bile-salt/cholesterol ratio in the bile (Thureborn, 1962), and this could lead to precipitation of cholesterol (Small, 1968). This ratio was not measured in the present study, but it is noteworthy that large radiolucent "cholesterol" stones were not the usual finding. Furthermore, gross bile salt deficiency-that is, steatorrhoea-was present in only a few patients, and in them gall stones were not especially common. It seems unlikely, therefore, that bile salt deficiency was the sole mechanism of gall stone production in these patients.

Excessive exposure of bile acids to colonic bacteria is inevitable with even minor ileal malabsorption (Hofmann, 1967). Microbially degraded bile acids are in general poorly soluble in water but they are partially absorbed. Lithocholic acid, the product of bacterial reduction of chenodeoxycholic acid, has been used to induce gall stone formation in rats (Palmer and Hruban, 1966 ; Zaki et al., 1967). The stones formed in this way consist mainly of the calcium salts of free or glycineconjugated lithocholic acid and its derivative $6 \beta$-hydroxylithocholic acid. The glycine conjugate of lithocholic acid is much less soluble than the taurine conjugate (Small, 1968), and a high $\mathrm{G} / \mathrm{T}$ ratio appears to be a prerequisite for lithocholate stone formation. This condition was met with in the patients in this study. Moreover, their gall stones were usually opaque and therefore rich in calcium. Chemical analysis of such gall stones will clearly be interesting.

The results of this study do not exclude the possibility that Crohn's disease itself (or its treatment) is related to cholelithiasis, irrespective of the location of the bowel lesion. Nevertheless, a necropsy study of unselected cases of Crohn's disease (Chapin et al., 1956) showed a lower incidence of gall stones5 out of $39(12.8 \%)$-than was found in the present investigation, in which minor ileal disease and non-ileal disease were excluded.

Since the gall stones of patients with ileal disorders are often opaque they will frequently be discovered accidentally. Chole- cystectomy should not necessarily be advised, since usually the stones cause no trouble and the gall bladder retains some function. In dogs, cholecystectomy increases the steatorrhoea of ileal resection (Jordan et al., 1968).

The pathogenesis of gall stone formation in patients with ileal disorders is not necessarily the same as that of the usual " idiopathic" gall stone. Analysis of unselected gall stones, however, has shown that their centres contain an excess of glycine-conjugated bile acids and very little deoxycholic acid, findings which suggest that the enterohepatic circulation was interrupted at the genesis of the stone (Schoenfield et al., 1966).

We are indebted to numerous clinicians for permission to study patients under their care, especially Dr. J. M. Naish, Dr. R. H. Salter, Dr. I. S. Bailey, and Dr. C. F. McCarthy. Our thanks are due to Dr. J. Roylance for help in interpreting the radiographs. We are grateful to Dr. S. T. Heaton for the bile salt assays. We also thank Miss E. H. L. Duncan for help with the statistical analyses.

\section{REFERENCES}

Austad, W. I., Lack, L., and Tyor, M. P. (1967). Gastroenterology, 52, 638.

Chapin, L. E., Scudamore, H. H., Baggenstoss, A. H., and Bargen, J. A. (1956). Gastroenterology, 30, 404.

Garbutt, J. T., Heaton, K. W., Lack, L., and Tyor, M. P. (1969). Gastroenterology, 56, 711.

Gordon, I. R. S. (1953). Quarterly fournal of Medicine, 22, 261.

Gross, D. M. B. (1929). Fournal of Pathology and Bacteriology, 32, 503.

Hardison, W. G. M., and Rosenberg, I. H. (1967). New England fournal of Medicine, $277,337$.

Heaton, K. W. (1968). M.D. thesis, University of Cambridge.

Heaton, K. W., Austad, W. I., Lack, L., and Tyor, M. P. (1968). Gastroenterology, 55, 5.

Hofmann, A. F. (1967). Gastroenterology, 52, 752.

Horn, G. (1956). British Medical fournal, 2, 732.

Jordan, P. H., Olson, R., and Paige, R. (1968). Surgery, 64, 446.

Kozoll, D. D., Dwyer, G., and Meyer, K. A. (1959). Archives of Surgery, 79, 514.

Krone, C. L., Theodor, E., Sleisenger, M. H., and Jeffries, G. H. (1968). Medicine, 47, 89.

Lieber, M. M. (1952). Annals of Surgery, 135, 394.

McLeod, G. M., and Wiggins, H. S. (1968). Lancet, 1, 873.

Palmer, R. H., and Hruban, Z. (1966). Fournal of Clinical Investigation, 45, 1255 .

Rominger, C. J., and Lockwood, D. W. (1963). American fournal of Surgery, 106, 89.

Schoenfield, L. J., Sjövall, J., and Sjövall, K. (1966). Fournal of Laboratory and Clinical Medicine, 68, 186.

Shehadi, W. H. (1966). Radiologic Clinics of North America, 4, 463.

Sherlock, S. (1968). Diseases of the Liver and Biliary System, 4th ed. Oxford, Blackwell.

Sjövall, J. (1960). Clinica Chimica Acta, 5, 33.

Sleisenger, M. H. (1967). In Cecil and Loeb Textbook of Medicine, 12 th ed., edited by P. B. Beeson and W. McDermott. Philadelphia, Saunders.

Small, D. M. (1967). Gastroenterology, 52, 607.

Small, D. M. (1968). New England Fournal of Medicine, 279, 588.

Tabaqchali, S., and Booth, C. C. (1966). Lancet, 2, 12.

Tabaqchali, S., Hatzioannou, J., and Booth, C. C. (1968). Lancet, 2, 12.

Thureborn, E. (1962). Acta Chirurgica Scandinavica, Suppl. No. 303.

Torvik, A. and Høivik, B. (1960). Acta Chirurgica Scandinavica, 120, 168.

van Deest, B. W., Fordtran, J. S., Morawski, S. G., and Wilson, J. D. (1968). Fournal of Clinical Investigation, 47, 1314.

Wenckert, A., and Robertson, B. (1966). Gastroenterology, 50, 376.

Zaki, F. G., Carey, J. B., Hoffbauer, F. W., and Nwokolo, C. (1967). fournal of Laboratory and Clinical Medicine, 69, 737. 